\title{
Analysis on the Role of Government in College Students' Innovation and Entrepreneurship
}

\author{
Liu Yuntao \\ Xijing University, Xi'an, Shaanxi, China, 710123
}

Keywords: college students; innovation and entrepreneurship; the role of government

\begin{abstract}
The government is the executive organ of state power, the symbol, bearing and subject of a country's administrative power. The purpose of the government is to provide public goods and services to the public. At present, the government, colleges and universities and society are important influencing factors in the innovation and entrepreneurship system of college students. Among them, the government occupies the dominant position, which plays a decisive role in the innovation and entrepreneurship cultivation of college education. Whether it is in the cultivation of innovation and entrepreneurship ability, or in the process of starting a business, the governments play an important role. This paper analyzes the role of Chinese government in innovation and entrepreneurship of college students, elaborates its function form, and reflects the function of guiding and support of government in the innovation and entrepreneurship of college students.
\end{abstract}

\section{Introduction}

The important function of service-oriented government is to provide public goods and services to the public. The government is the architect and executor of innovation and entrepreneurship preferential policies and application conditions for college students. The government protects the legal rights and interests of college students' innovation and entrepreneurship and enjoy various preferential policies within the policy range through legal documents. In the process of college students' innovation and entrepreneurship, the main function of government is to optimize the social environment of college students' entrepreneurship. The government reduces the threshold for college students to start their own business, and protects the innovation and entrepreneurship of college students by increasing the support strength and preferential policies for college students' entrepreneurship. It can be said that the role of the government goes deep into the innovation and entrepreneurship awareness of college students and the cultivation of their abilities to the whole process of entrepreneurship. The influence is decisive, strategic and real-time.

\section{The Role of the Government}

\subsection{Administrative organs.}

In accordance with the functions of China's administrative organs, the government departments in China have direct links with university students in innovation and entrepreneurship, including education, technology, human resources and social security. These departments involve the establishment, implementation, supervision and other functions of college students' innovation and entrepreneurship preferential policies. For example, the ministry of education and other departments are responsible for the construction of basic knowledge and capacity building of universities. The department is mainly responsible for the cultivation of talents in various universities. The department of science and technology is mainly responsible for the innovation and innovation of scientific and technological innovation in college students' innovation and entrepreneurship, and make the declaration and preferential policies for scientific and technological innovation. The department of human resources and social security is responsible for the construction of innovation and entrepreneurship system for college students, and is responsible for the establishment of incubation parks or innovation and entrepreneurship bases established by the government and 
universities. It is also responsible for the preferential policies of innovation and entrepreneurship tax and the basic rights of college students.

\subsection{Higher education organization.}

The institution of innovation and entrepreneurship education for college students in China are mainly universities, research institutes, and social support entrepreneurship institutions. Colleges and universities as the institutions to undertake the government's innovation and entrepreneurship awareness, knowledge and practical ability of university students, which is very important. In college students' innovation and entrepreneurship cultivation, universities mainly have the following important responsibilities. First, pay attention to the cultivation of students' innovative consciousness and cultivate their ability to apply innovative consciousness to work and life. Second, encourage students to develop personalized thinking, and do not imprison their own thoughts. Thirdly, when cultivating the individualized thinking, we should pay attention to the avoidance of the sprout of individualism. Fourthly, different forms of students' different characteristics are cultivated to cultivate their innovative spirit.

\subsection{Social intermediary service agencies.}

China's social intermediary service agencies can provide a great deal of information, technology, market, financing and other services. In order to meet the technical bottleneck, sales operation, shortage of capital chain, etc. This kind of organization optimizes market resource allocation, it is the necessary process that Chinese society establishes fair and just competition environment, and it is the important safeguard that adjusts and perfect Chinese economy market. Such intermediary services mainly include human resource institutions, accounting firms, law firms, business incubators, financial services institutions, credit rating agencies, etc. And these intermediaries are closely related to the Chinese government, mainly business incubators and financial services institutions. However, these institutions are mostly state-owned enterprises and are willing to provide their own strength for China to support the innovation and entrepreneurship of university students.

\section{The Function Form of Government}

\subsection{Formulation of policies.}

The role of the Chinese government in the innovation and entrepreneurship of college students is mainly based on the formulation and improvement of policies and measures according to the needs of development. And then attract and encourage college students to innovate and start their own businesses through these measures. The government formulates the incentive mechanism suitable for local development according to the social influence factors. The incentive system formulated by the Chinese government mainly includes preferential policies, subsidizing policies, guiding policies and supportive policies. And as a local government that implements, refines and implements these provisions. It is necessary to ensure that such policies meet local characteristics. We can better instruct local colleges and universities to carry out innovation and entrepreneurship work for college students. However, according to the factors that the Chinese government divides into administrative functions, the preferential policies and measures formulated by various departments are difficult to form a complete system. And those policies are hardly uniform.

For example, the preferential policies formulated by the ministry of education are definitely more inclined to the supportive policies of education in China. The focus of such policies is mainly on the support of the basic construction of teaching, practice base and incubator in universities. The preferential policies formulated by the ministry of science and technology must be more inclined to reward and declare innovative technologies and technologies. However, the cultivation of college students' innovation and entrepreneurship ability will be seldom mentioned. And the ministry of human resources and social security will be more inclined towards the employment rate and entrepreneurship rate of college graduates, and attract college students to start their own businesses 
by setting up preferential policies for entrepreneurship. It is precisely because of the division of the functions of Chinese government departments that it is difficult for China to issue a document suitable for the complete system of innovation and entrepreneurship of university students.

\subsection{Strategic planning.}

The Chinese government is responsible for the overall planning of various service systems for college students' innovation and entrepreneurship, including policies, education, practice, incubation park and other service systems. In this strategic plan, the government agencies involved in the strategic planning involve the ministries of education, science and technology, human resources and social security. Various service systems in strategic planning are implemented and supervised by responsive government departments. For example, the education system of colleges and universities is mainly responsible for the planning and implementation of the ministry of education and the supervision of the final result. The practice system is jointly implemented and supervised by the ministry of education and the ministry of science and technology. The platform or base of college students' innovation and entrepreneurship practice mainly includes entrepreneurship competition, training base, incubation park, etc. However, the establishment of these practical platforms and bases in colleges and universities is not feasible for the rational planning of Chinese government departments, and the support of social groups is inseparable. Through the strategic planning of university students' innovation and entrepreneurship, the Chinese government completes the systematic construction of innovation and entrepreneurship. In order to optimize the allocation of resources in China's economic market, we can achieve the optimization and intercommunication of each platform.

\subsection{Resource allocation.}

The important means for the Chinese government to influence the innovation and entrepreneurship activities of university students is the optimal allocation of resources. The government is equipped with social resources through direct and indirect means. The direct way is to attract college students' innovation and entrepreneurship through special funds, government financial subsidies and tax exemption. On the one hand, it can attract and mobilize social capital injection, on the other hand, it can directly allocate funds for intervention. The indirect method is mainly tax deduction and some administrative resources investment.

\subsection{Environmental construction.}

The Chinese government has issued a number of documents, including preferential policies, subsidized policies, guided policies and supportive policies. And the Chinese government has increased its publicity of such policy documents to attract the attention of social groups. And through the public opinion to create a suitable atmosphere for college students to start a business. At the same time, the Chinese government intervenes through the market economy to create a good entrepreneurial environment for the innovation and entrepreneurship of college students. The Chinese government pays more attention to the overall layout of innovation and entrepreneurship for college students. It is hoped that by creating a social environment to enhance the cultivation of university students' awareness, ability and quality of innovation and entrepreneurship, and attract college students to start their own business.

\section{Conclusion}

Innovation is the soul of a nation's progress. The key to innovation lies in young people, including college students, who are dynamic, creative, and resourceful in exploring the unknown and novel fields. The cultivation of college students' scientific and technological innovation ability is the basic, source and strategic component of the national innovation system. It is an important basis for the national talent development strategy and innovation-driven development strategy. The role of the government goes deep into the innovation and entrepreneurship awareness of university students and the cultivation of their ability to the whole process of entrepreneurship, and this 
influence is decisive, strategic and real-time.

\section{References}

[1] Busenitz L W. West III G P,et a1.Entrepreneurship Research in Emergence: Past Trends and Future Directions. Journal of Management (2003) pp 285 - 308

[2] Shane. Venkataraman. Macmillan 2005 Cultural differences in innovation championing strategies. Manage (2005) pp 931-953

[3] Belinda Luke, Martie Louise Verreynne, Kate Kearins. Innovative and entrepreneurial activity in the public sector: The changing face of public sector institutions. Innovation (2010) pp 138 - 153

[4] Semra Guven. World Conference on Edueational Seiences New primary edueationcourse programmes and entrepreneurship. Proeedia Social and Behavioral Seiences (2009) pp 265-270

[5] Mclagan. Great ideas revisited. Training and Development (1996) pp 60-65

[6] Einar A, Rasm Jssen Roger Sorheim. Aetiorr-based. eneurship edueation. Ten Teehnovation (2006) pp 185

[7] HelgeBerglann; EsPenR. Moen, KnutRoed, etal. Entre PreneurshiP: Origins and returns. Labour Eeonomies (2011) pp 180-193 